\title{
NATURAL GAS HEAT COMBUSTION DETERMINATION ON MEASURING SYSTEMS WITH DUPLICATE GAS UNITS
}

\section{ВИЗНАЧЕННЯ ТЕПЛОТИ ЗГОРЯННЯ ПРИРОДНОГО ГАЗУ НА ВИМІРЮВАЛЬНИХ СИСТЕМАХ З ДУБЛЮЮЧИМИ ВУЗЛАМИ ОБЛІКУ ГАЗУ}

\section{Igor Petryshyn ${ }^{1}$ \\ Olexandr Bas ${ }^{2}$}

DOI: https://doi.org/10.30525/978-9934-26-001-8-2-8

Abstract. The paper focuses on the need to determine the natural gas heat combustion in order to transition to gas metering in units of energy. The technical organization of gas transportation in the main and distribution pipelines on the territory of Ukraine is shown. A detailed analysis of regulatory and legal support, which regulates the definition and accounting of quantitative and qualitative characteristics of natural gas at gas metering units. The draft Rules for determining the natural gas volume are considered in detail. Specified variants of determining the weighted average value of combustion heat in the case of complex gas supply systems with the use of flow measuring means of gas combustion heat. The necessity and urgency of determining the natural gas heat combustion on measuring systems, which are equipped with duplicate metering units without the installation flow means measuring the heat combustion. Emphasis is placed on the fact that a large number of measuring systems are built on the method of variable pressure drop with the use of standard orifice devices. It is pointed out that this method, according to its physical principle, measures the mass gas flow rate. It is also stipulated that ultrasonic gas meters are often used to complete duplicate metering units. The advantages of ultrasonic meters are given. Attention is drawn to the availability of technical metrological support in Ukraine on the basis calibration prover, which includes two secondary

\footnotetext{
${ }^{1}$ Doctor of Technical Sciences, Professor, Chief Researcher,

SE "Ivano-Frankivskstandartmetrology", Ukraine

${ }^{2}$ Candidate of Technical Sciences, Senior Researcher,

SE "Ivano-Frankivskstandartmetrology", Ukraine
} 
standards gas volume and volume flow rate units. Methods and technical means for determining the natural gas heat combustion are analyzed. The calculation of the gas heat combustion and the Wobbe number based on the density values is shown. It is noted that the value of the gas mass flow rate is related to the value of the gas volume flow rate precisely the value of density. The nonlinear dependence of the gas mass heat combustion for the density, which is associated with a disproportionate change in the percentage of carbon atoms to hydrogen atoms, is shown. The structural scheme of the measuring system with the duplicating metering unit for gas density definition and gas heat combustion calculation is developed. The density calculation and natural gas heat combustion depending on the molar fraction of nitrogen and carbon dioxide in the gas from the minimum to the maximum value is carried out. The linear dependence of the change in the gas heat combustion for the molar fraction of nitrogen is established, on the basis of which the method of controlling the gas heat combustion for measuring systems with a duplicate metering unit is proposed. It is shown that the developed procedure for determining the natural gas heat combustion based on the value of density, which is obtained from the calculation of gas mass flow rate and gas volume flow rate consumption on measuring systems with duplicate metering units exactly satisfies class B and C according to DSTU OIML R 140.

\section{1. Вступ}

Мережа магістральних та розподільних газопроводів України, яку обслуговують, за виключенням трубопровідних мереж видобувних компаній, які, зазвичай, не $є$ постачальниками газу кінцевому споживачу, ТОВ «Оператор газотранспортної системи (ГТС) України» та АТ «Регіональні газові компанії(РГК)», є надзвичайно розгалуженою та логістично ускладненою. Для прикладу, на рис. 1 наведений фрагмент схематичного суміщеного розташування магістральних та розподільних газопроводів на території кількох областей України 3 позначенням кінцевих точок із значенням вихідного середнього тиску (від 5 кПа до 300 кПа).

Природний газ, який транспортується системою магістральних газопроводів, потрапляє в неї у: 43 вхідних точках міждержавного з'єднання, 3 врахуванням вхідних точок реверсу природного газу 


\section{Igor Petryshyn, Olexandr Bas}

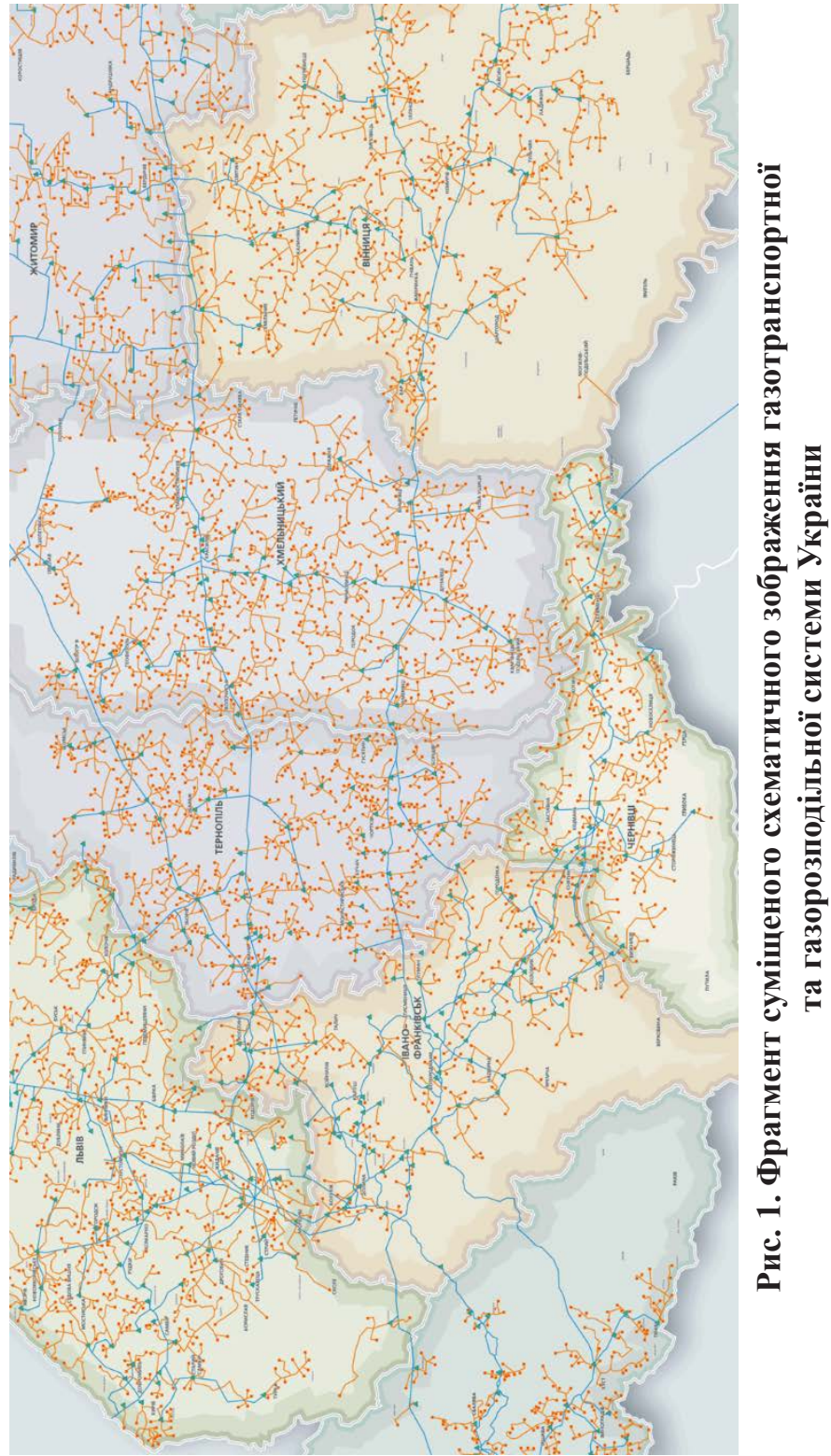


3 Польщі, Словаччини, Угорщини та Молдови, 21 вхідній точці 3 підземних сховищ газу та 147 вхідних точок газовидобувних компаній на території країни. Аналогічно організована система точок виходу із газотранспортної магістральної системи в систему розподільчих газопроводів та мереж, яких налічується 1603. В переважній більшості, в точці виходу знаходиться газорозподільна станція 3 автоматизованою системою контролю та обліку природного газу або пунктом вимірювання витрати газу. Крім того, аналогічним чином організований комерційний облік природного газу в системі розподільних та газозбутових трубопроводів та мереж.

\section{2. Аналіз нормативної бази}

В залежності від об'ємів транспортованого природного газу та максимального значення об'ємної витрати газу, відповідно до комплексу нормативних документів, які регламентують роботу та встановлюють вимоги до газотрубопровідної системи України, а саме: Кодексів [1-3] та Правил обліку природного газу під час його транспортування газорозподільними мережами, постачання та споживання [4], визначені категорії автоматизованих систем контролю та обліку природного газу (вузлів обліку газу - ВОГ) та, відповідно, зазначені рекомендовані законодавчо регульовані засоби вимірювальної техніки - лічильники та коректори (обчислювачі) газу для здійснення комерційного обліку. Що стосується Правил обліку газу [4], то даний нормативний документ в деякій мірі не відповідає чинному на даний час законодавству та потребує приведення у відповідність до вимог діючих нормативних документів на підзаконних актів, в тому числі Закону України «Про ринок природного газу» [5].

Міністерством палива та енергетики України розроблений проект Правил визначення обсягів природного газу [6] на заміну діючому нормативному документу [4]. Ці Правила повинні розповсюджуватись та стосуватись суб' єктів внутрішнього ринку природного газу, та не поширюватись на міждержавні та прикордонні газовимірювальні станції (ГВС). Зокрема проект [6] мав на меті встановити чіткий перелік вимог до складових частин ВОГ, їх метрологічних характеристик, правил експлуатації приладів для визначення фізикохімічних показників природного газу та його обсягу в одиницях 
енергії, як того вимагає Закон [5]. Також, для підвищення надійності обліку природного газу та покращення достовірності вимірюваного об'єму природного газу рекомендовано суб'єктам ринку природного газу встановлювати дублюючі ВОГ. Аналогічні рекомендації щодо встановлення дублюючих ВОГ зазначені у Кодексах [1-3]. Що стосується засобів обліку об'єму природного газу, то для комплектації в складі ВОГ необхідно застосовувати витратоміри змінного перепаду тиску, лічильники та коректори (обчислювачі), які пройшли оцінку відповідності вимогам Технічного регламенту засобів вимірювальної техніки [7] та допущені до введення в обігу на території України. Рекомендованими є лічильники: турбінного, роторного, ультразвукового i мембранного типів та вимірювальні комплекси на базі роторних та турбінних лічильників, які об'єднують в собі лічильник та коректор газу. Крім того, відповідно до вимог Технічного регламенту законодавчо регульованих засобів вимірювальної техніки [8], усі автоматизовані системи контролю і обліку природного газу, що містять програмний продукт (ВОГ) і які вводяться в експлуатацію для комерційного обліку, повинні пройти процедуру оцінки відповідності за модулями F1 або G.

Особлива увага в документі приділена визначенні енергії природного газу, шляхом добутку об'єму спожитого газу на представницьке значення його теплоти згоряння (теплотворної здатності). Встановлений ряд вимог щодо засобів вимірювання теплоти згоряння, в тому числі до їх метрологічних характеристик, до розташування та монтажу у складі ВОГ. Розподілено засоби, які здійснюють вимірювання теплоти згоряння газу в потоці в режимі реального часу та лабораторні засоби, які проводять визначення представницького значення теплоти згоряння з відібраної проби. Разом 3 тим, передбачений розрахунок середньозваженого представницького значення теплоти згоряння у разі надходження природного із різних джерел із різним значенням фізико-хімічних показників (ФХП). Зокрема, конкретизовані наступні випадки: у разі входу газу в систему газопроводів одночасно із різних джерел із різними значеннями ФХП через ВОГ, які не обладнані потоковими ЗВТ визначення теплоти згоряння; коли в систему газопостачання газ потрапляє через ВОГ, обладнаний потоковим засобом; коли в системі декілька вхідних ВОГ, 
які обладнані потоковими засобами або ж коли в системі вхідний ВОГ обладнаний потоковим засобом визначення теплоти згоряння газу, але у внутрішній системі також наявний ВОГ, який містить потокові засоби. Крім того, зазначено, що у разі застосування складних систем газопостачання із різними типами та категоріями ВОГ, для визначення середньозваженого представницького значення теплоти згоряння природного газу, необхідно застосовувати метод реконструкції стану, рекомендації щодо якого зазначені в стандарті ДСТУ ISO 15112 [9].

Слід відзначити, що система магістральних газопроводів розділена на 340 маршрутів, які пов'язані з точками входу - виходу, про які зазначено вище. ТОВ «Оператор ГТС України» надає щоденні паспорти фізико-хімічних показників природного газу, в яких вказане значення теплоти згоряння, густини природного газу та інших показників, по кожному із маршрутів. Визначення ФХП газу проводиться в вимірювальних хіміко-аналітичних лабораторіях Оператора та на ВОГ, які обладнані потоковими хроматографами. Таким чином здійснюється розрахункова екстраполяція значення теплоти згоряння природного газу, який надходить до споживача, по кожному маршруту. Ці дані з паспортів ФХП природного газу використовуються РГК для формування платіжних документів споживачам.

Iз зазначеного слідує, що питання визначення репрезентативного представницького значення теплоти згоряння природного газу на ВОГ, які не обладнані потоковими засобами і які знаходяться в складній системі газопостачання, в яку може надходити природній газ із різних джерел із різними значеннями ФХП, є актуальною задачею.

Метою дослідження $\epsilon$ розроблення процедури визначення представницького значення теплоти згоряння та числа Воббе природного газу на ВОГ, які обладнано додатковим дублюючим ВОГ без встановлення потокових засобів вимірювання теплоти згоряння природного газу.

\section{3. Технічне забезпечення ВОГ}

Велика кількість існуючих ВОГ в Україні експлуатується досить тривалий термін. Зважаючи на особливості діючих на той момент нормативних документів, наприклад [10] та наявного технічного забезпечення, основний відсоток ВОГ проводить вимірювання кількості спожитого природного газу із застосуванням методу змінного 
перепаду тиску, використовуючи стандартні звужуючі пристрої (діафрагми). Великого розповсюдження метод змінного перепаду тиску набув через простоту застосування та відсутність необхідності у забезпеченні технічного метрологічного забезпечення (повірочних установок, які імітують рух газового потоку), оскільки розрахунок витрати газу проводиться на основі значення перепаду (втрати) тиску, зумовленого звуженням потоку, фізичних параметрів звужуючого пристрою та вимірювальних трубопроводів, які отримуються шляхом проведення геометричних та механічних вимірювань.

Крім того, метод змінного перепаду тиску із застосуванням стандартних звужуючих пристроїв апріорі, за своїм фізичним принципом, на основі рівняння Бернуллі для двох перерізів трубопроводу, здійснює вимірювання значення саме масової витрати газу [11]. Значення якої, в свою чергу, є доволі інформативним параметром, наприклад, для видобувних компаній або кінцевих споживачів, які використовують природній газ для технологічних процесів, пов'язаних із безпосереднім спалюванням, оскільки для пальників, які за своїм принципом дії $\epsilon$ звужуючими пристроями, для стандартизованих умов функціонування яких, нормується саме значення масової витрати газу.

Відповідно, зазвичай, практика встановлення дублюючих послідових ВОГ полягає у застосуванні у складі дублюючого вузла іншого методу вимірювання витрати та кількості газу. Типовою схемою обладнання дублюючої системи є застосування лічильників різних типів, зокрема: турбінного та ультразвукового (швидкісний тип) або роторного (об'ємний тип). Вибір типу лічильника здійснюється в залежності від значення об'ємної витрати газу та технічної можливості встановлення лічильника із дотриманням необхідних параметрів (діаметра трубопроводу, розмірів вхідних та вихідних прямих ділянок, фізико-хімічних параметрів газу, температурних умов експлуатації лічильника, визначені віддалі розміщення давачів вимірювання тиску і температури та інших).

\section{4. Лічильники газу ультразвукового типу на дублюючих вузлах}

Підвищеним попитом серед лічильників, за умови ідентичних вихідних даних, користуються лічильники газу ультразвукового типу. Така особливість пов'язана із комплексними перевагами, які присутні 
при застосуванні такого типу лічильників. Зокрема: на ринку присутня велика кількість конкурентно-здатних виробників, в тому числі i вітчизняних, які освоїли виробництво та провели оцінку відповідності ультразвукових лічильників дво- та чотирьох-променевих, що суттєво підвищує їх точність, шляхом зменшення випадкової складової та достовірність вимірювань. На основі проведених випробувань, можна стверджувати з високою ймовірністю, що ці лічильники мають стабільніші метрологічні характеристики в частині довготермінової стабільності, ніж лічильники інших типів. Також, зважаючи на конструктивні особливості ультразвукових лічильників, у них відсутні будь-які рухомі механічні елементи, що, безумовно, також надає перевагу перед аналогічними турбінними (швидкісними) та роторними (об'ємними) лічильниками, оскільки ці лічильники менше піддаються впливу змін фізико-хімічних характеристик газу та, відповідно, механічного зносу. Крім того, на покази ультразвукового лічильника газу не впливають властивості робочого середовища, об'ємну витрату якого він вимірює. Базова схема проведення вимірювань швидкості газового потоку у вимірювальному тракті ультразвукового лічильника показана на рис. 2 на прикладі одного променя.

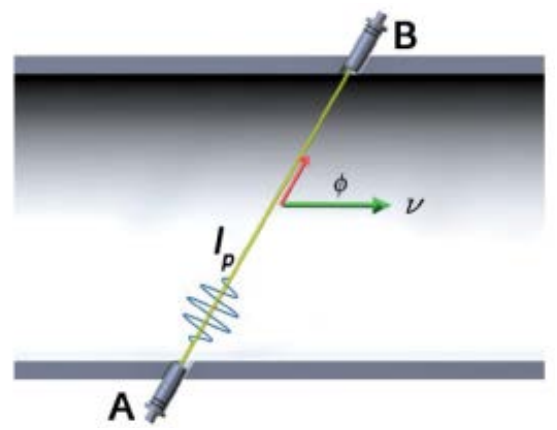

Рис. 2. Схема визначення швидкості газового потоку

на основі часових інтервалів проходження ультразвукових хвиль в корпусі лічильника $v$ - швидкість газового потоку;

$\phi$ - кут нахилу випромінювачів ультразвукових хвиль; $l_{p}$ - довжина траєкторії проходження ультразвукових хвиль 
Швидкість газового потоку, відповідно до формули (1) [12], як інформативний параметр, визначається на основі геометричних параметрів встановлення ультразвукових випромінювачів (перетворювачів) в корпусі лічильника, площа поперечного перерізу якого є показником для розрахунку об'ємної витрати газу:

$$
v=\frac{l_{p}}{2 \cdot \cos \varphi} \cdot\left(\frac{1}{t_{A B}}-\frac{1}{t_{B A}}\right)
$$

де $t_{A B}, t_{B A}$ - часові проміжки проходження ультразвукових хвиль (імпульсу) за потоком від точки А до В, та, відповідно, в зворотному напрямку проти потоку, від В до А (рис. 2).

Сучасні ультразвукові лічильники зазвичай обладнані внутрішнім вбудованим обчислювачем із системою самодіагностики та багатопараметричної корекції показів виміряного значення об'єму та об'ємної витрати газу, в частині визначення зміни геометрії корпусу лічильника за даними вбудованих давачів тиску і температури та числа Рейнольдса газового потоку. Також важливою функцією цих лічильників є можливість здійснення їх повторного градуювання, тобто зміщення його метрологічної характеристики для максимального наближення іiї до горизонтальної нульової осі шляхом застосування декількох, передбачених виробником, варіантів корегування, в тому числі і поліноміальну корекцію.

Ще одним основоположним фактором широкого застосування ультразвукових лічильників в складі дублюючих ВОГ, стала наявність технічного метрологічного забезпечення в Україні. Це, в свою чергу, дало можливість реалізації проведення метрологічних робіт із випробувань, оцінки відповідності, калібрування, повірки та градуювання ультразвукових лічильників з умовним діаметром Ду300 мм на калібрувальній установці наукового метрологічного центру ДП «Івано-Франківськстандартметрологія» [13]. Калібрувальна установка функціонує на базі двох вторинних еталонів одиниць об'єму та об'ємної витрати газу України ВETУ 03-01-03-11 та ВЕТУ 03-01-04-12 в діапазоні об'ємної витрати від $1 \mathrm{~m}^{3} /$ год до $7800 \mathrm{~m}^{3} /$ год, що, в свою чергу відповідає значенню максимальної об'ємної витрати газу для ультразвукових лічильників газу зазначеного діаметра. 
Слід відзначити, що основними замовниками лічильників ультразвукового типу для встановлення їх в якості дублюючих на вузлах обліку газу, за результатами вимірювань яких проводяться комерційні розрахунки, є: ТОВ «Оператор ГТС України», АТ «Укртрансгаз», як оператор газових підземних сховищ, Регіональні газові компанії в точках виходу з системи магістральних газопроводів, AT «Укргазвидобування» та приватні газовидобувні компанії, які здійснюють передачу видобутого природного газу через точки входу в систему магістральних газопроводів. Термін газова «точка входу / виходу» визначена в гармонізованому стандарті ДСТУ EN 16726 [14].

\section{5. Теплота згоряння природного газу}

Що стосується питання визначення представницького репрезентативного значення теплоти згоряння (теплотворної здатності) природного газу, то, у відповідності до нормативних документів [15], передбачено застосування одного з наступних методів: прямих вимірювань, який реалізовується шляхом безпосереднього спалювання відібраної проби природного газу в калориметрі; непрямих вимірювань, який базується на попередньому визначенні компонентного складу природного газу хроматографом та опосередкованого методу, побудованого на визначенні кореляційної залежності між значенням теплоти згоряння та фізико-хімічними показниками природного газу. Відповідно до розробленого проекту Правил [6], для визначення теплоти згоряння природного газу передбачено застосування наступних законодавчо регульованих засобів вимірювальної техніки: хроматографів, густиномірів, спектральних газоаналізаторів та калориметрів.

Зупинимось детальніше на нормативно-методичному забезпеченні визначення теплоти згоряння природного газу на основі вимірювання параметра густини газу. На основі попередніх досліджень, авторами встановлено наявність лінійної залежності між значення густини (кг/м $\left.{ }^{3}\right)$ горючих вуглеводневих компонентів природного газу та їх об'ємною теплотворною здатністю (МДж/м³) [16]. Тобто, при збільшенні густини (молярної маси) компонентів газу, зростає і значення їхньої об'ємної теплоти згоряння Проте, при аналізі величини масової теплоти згоряння (МДж/кг) вуглеводневих компонентів природного газу, 
характер кривої має обернену залежність 3 нелінійним характером (рис. 3). Такий характер кривої пояснюється непропорційною зміною процентного співвідношення атомів карбону (вуглецю) С до атомів гідрогену (водню) $\mathrm{H}$ в молекулі газу типу $\mathrm{C}_{\mathrm{n}} \mathrm{H}_{2 \mathrm{n}+2}$, яке складає від $25 \% \mathrm{C} / \mathrm{H}$ у метані $\left(\mathrm{CH}_{4}\right), 33,33 \% \mathrm{C} / \mathrm{H}$ у етані $\left(\mathrm{C}_{2} \mathrm{H}_{6}\right)$ і до $42,85 \% \mathrm{C} / \mathrm{H}$ у гексані $\left(\mathrm{C}_{6} \mathrm{H}_{14}\right)$. Таким чином, з врахуванням існуючого, затвердженого на законодавчому рівні, обліку природного газу та визначення значення його теплоти згоряння в об'ємних одиницях, слід відзначити, що найбільш ефективним з точки енергозатратності та енергоефективності, у разі безпосереднього спалювання в газоспоживаючому обладнанні, $\epsilon$ метан, як основний компонент природного газу. Його мінімально допустимий процентний об'ємний вміст в природному газі, що транспортується, встановлений в [1] і складає не менше 90\%.

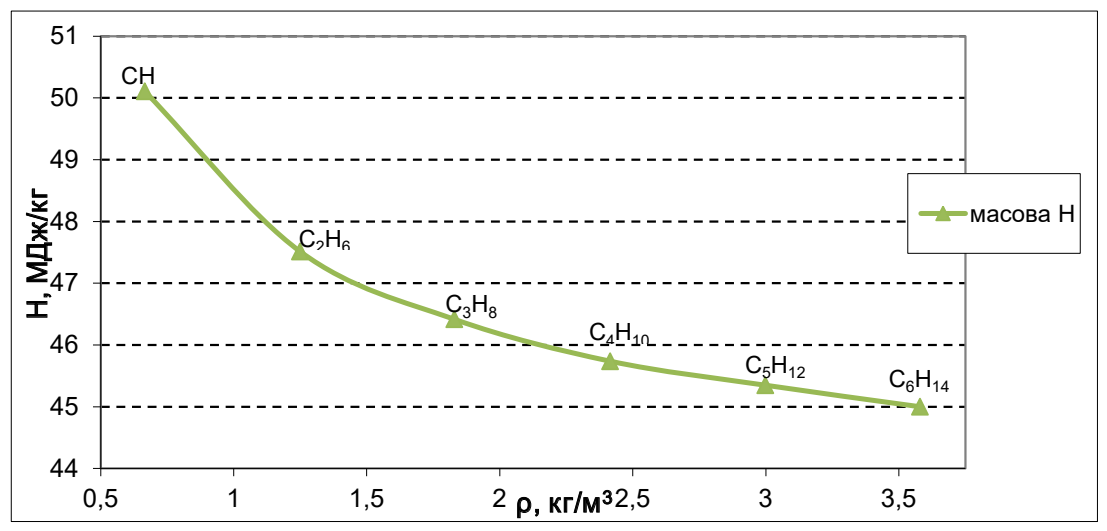

Рис. 3. Залежність значення масової теплоти згоряння компонентів $\mathrm{C}_{\mathrm{n}} \mathrm{H}_{2 \mathrm{n}+2}$ природного від їх густини

3 врахуванням того, що типовий склад природного газу входять, крім вуглеводневих і інші горючі (сірковмісні) та не горючі (азот, кисень та інші) компоненти, тому для визначення вищої $H_{G}$ та нижчої $H_{N}$ теплоти згорання природного газу, на основі здійсненого аналізу та встановлених закономірностей, в залежності від його густини доцільніше використовувати наступні стандартизовані кореляційні залежності [17]: 


$$
\begin{aligned}
& H_{G}=92,819 \cdot\left(0,51447 \cdot \rho_{c}+0,05603-0,65689 \cdot x_{a}-x_{y}\right) \\
& H_{N}=85,453 \cdot\left(0,52190 \cdot \rho_{c}+0,04242-0,65197 \cdot x_{a}-x_{y}\right)
\end{aligned}
$$

де $\rho_{c}-$ густина газу за стандартних умов;

$x_{a}$ - молярна частка азоту (N2) в газі;

$x_{y}$ - молярна частка діоксиду вуглецю $\left(\mathrm{CO}_{2}\right)$ в газі.

Крім того, важливим показником природного газу є число Воббе, яке $\epsilon$ свого роду комплексним показником якості газу, оскільки визначається на основі аналітичної залежності, яка пов'язує два окремі показники: теплоту згоряння природного газу та його відносну густину. Показник відносної густини по відношенню до густини повітря, пов'язаний із процесом горіння газу, оскільки для кожного iз горючих вуглеводневих компонентів природного газу нормується теоретична необхідна кількість повітря для його повного згоряння.

Число Воббе $є$ одним 3 критеріїв подібності різних типів газів та визначає їхню можливість взаємозамінності і охарактеризовує стабільність та незмінність енергії теплоти, яка вивільняється з газу в результаті його спалювання, незалежно від компонентного складу і $\epsilon$ параметричним показником для визначення коефіцієнту корисної дії (ККД) газоспоживачого обладнання. Таким чином, можна стверджувати, що гази з однаковим показником числа Воббе, при умові рівноцінного та стабільного надлишкового тиску газу, зазвичай можуть замінюватись один одним без додаткової заміни або регулювання пальників чи газових форсунок газоспоживаючого обладнання, які при виготовленні нормуються саме за показником числа Воббе природного газу.

Число Воббе визначається за наступною формулою:

$$
W=\frac{H}{\sqrt{d}}
$$

де $H$ - об'ємна вища або нижча теплота згоряння природного газу, відповідно визначається вище або нижче число Воббе природного газу;

$d$ - відносна густина природного газу, яка, як вказано вище, визначається як співвідношення густини газу $\rho_{c}$ до густини повітря $\rho_{A}$ :

$$
d=\frac{\rho_{c}}{\rho_{A}}
$$


В результаті підстановки формул (2), (3) та (5) у формулу (4), отримуємо аналітичні залежності для визначення вищого $W_{G}$ та нижчого $W_{N}$ значення числа Воббе природного газу:

$$
\begin{aligned}
& W_{G}=\frac{92,819 \cdot\left(0,51447 \cdot \rho_{c}+0,05603-0,65689 \cdot x_{a}-x_{y}\right)}{\sqrt{\frac{\rho_{c}}{\rho_{A}}}} \\
& W_{N}=\frac{85,453 \cdot\left(0,52190 \cdot \rho_{c}+0,04242-0,65197 \cdot x_{a}-x_{y}\right)}{\sqrt{\frac{\rho_{c}}{\rho_{A}}}}
\end{aligned}
$$

За умови встановлення на вузлі обліку газу із застосуванням методу змінного перепаду тиску на базі стандартного звужуючого пристрою дублюючої системи на базі лічильника газу ультразвукового, турбінного або роторного типів, значення густини природного газу можна визначити розрахунковим методом на основі фізичних основ вимірювання витрати газу різними принципами. Іншими словами, значення масової витрати газу $\left(q_{m}\right)$, яке вимірює стандартний звужуючий пристрій пов'язане із значенням об'ємної витрати газу $\left(q_{v}\right)$, виміряне лічильником наступною залежністю:

$$
q_{m}=q_{v} \cdot \rho_{c}
$$

Відповідно, густина природного газу $\rho_{c}$ визначатиметься згідно:

$$
\rho_{c}=\frac{q_{m}}{q_{v}}
$$

Також у формулах (6), (7) присутні впливові показники об'ємного вмісту в природному газі азоту та діоксиду вуглецю. Що стосується молярної частки діоксиду вуглецю, то для іiі визначення вузол обліку газу необхідно дообладнати потоковим інфрачервоним газоаналізатором вмісту $\mathrm{CO}_{2}$, по аналогії до тих, які застосовуються в автомобільній промисловості для оцінки викидів вуглекислого газу у відпрацьованих вихлопних газах. Таке дооснащення вузла обліку не передбачає внесення конструктивних або інших змін, оскільки проба газу для газоаналізатора може подаватися, для приладу, імпульсною трубкою відбору тиску. 


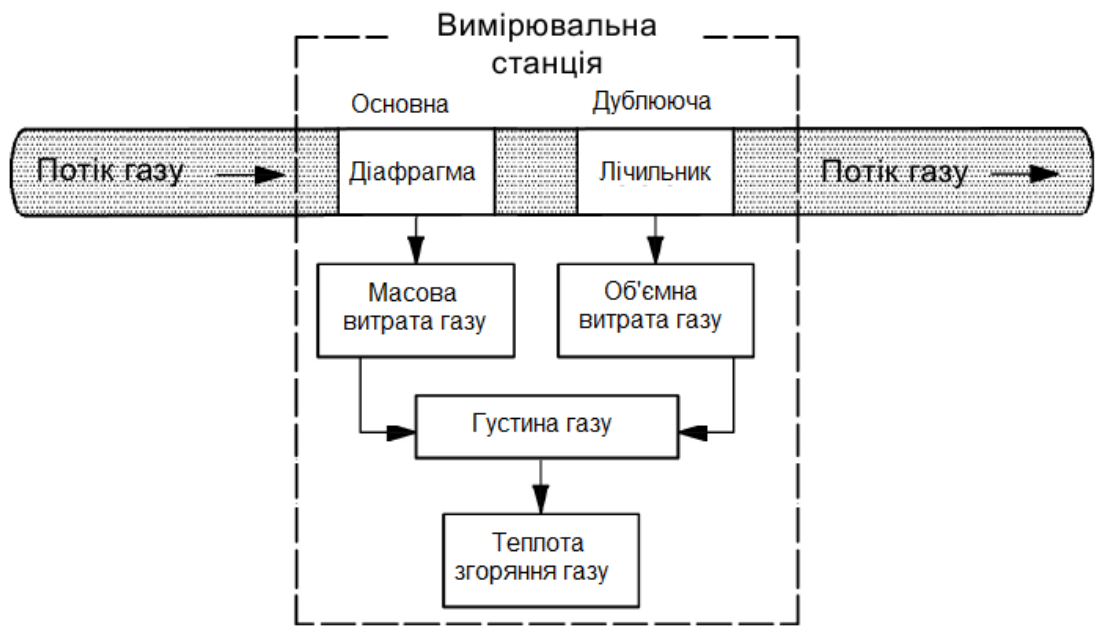

Рис. 4. Схема вимірювальної станції

3 функцією визначення теплоти згоряння природного газу на базі основної та дублюючої системи

На рис. 4 представлена схема вимірювальної станції обліку природного газу, до складу якої входять дві послідовно встановлені системи, побудовані на двох різних методах вимірювання витрати та об'єму природного газу. На прикладі такої станції показана реалізація алгоритму розрахунку теплоти згоряння природного газу із застосуванням значення густини газу, яке встановлене згідно формули (9). Оскільки типові вимірювальні станції, які обладнані дублюючими системами, зазвичай, для обліку природного газу в частині приведення до стандартних умов застосовують двохканальні обчислювачі, відповідно, для проведення розрахунку теплоти згоряння природного газу на основі значення густини необхідно додатково доповнити алгоритм розрахунку декількома формулами.

\section{6. Моделювання розрахунку густини та теплоти згоряння природного газу}

Слід відзначити, що максимальне значення об'ємного вмісту основних горючих та негорючих компонентів природного газу 
нормується в [1], і для діоксиду вуглецю $\left(\mathrm{CO}_{2}\right)$ він складає максимум $2 \%$, а для азоту $\left(\mathrm{N}_{2}\right)$ не повинен перевищувати 5\%. Разом 3 тим, унормований діапазон значень вищої та нижчої теплоти згоряння природного газу. Зокрема: для вищої теплоти згоряння природного газу

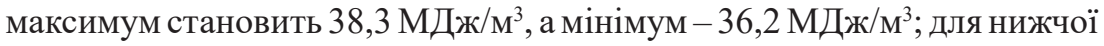
теплоти згоряння, максимум - 34,54 МДж/м³ мінімум - 32,66 МДж/м². Відносне відхилення різниці між максимальним та мінімальних значенням теплоти згоряння при цьому складає 5,6\%.

Для оцінки впливу вище вказаних впливових показників молярної частки азоту та діоксиду вуглецю в природному газі, проведемо теоретичне моделювання розрахунку густини та, відповідно, теплоти згоряння природного газу, значення якої не повинно виходити за вище зазначені законодавчо встановлені межі, згідно формул (2) і (3) за наступних вихідних даних:

- Вміст № 1 - максимально допустима молярна частка азоту (5\%) i діоксиду вуглецю (2\%);

- Вміст № 2 - вказані компоненти відсутні;

- Вміст № 3 - азот відсутній, молярна частка діоксиду вуглецю максимальна (2\%);

- Вміст № 4 - молярна частка азоту задана $1 \%$, молярна частка діоксиду вуглецю максимальна (2\%).

Результати моделювання наведено в таблиці 1.

Таблиця 1

Результати моделювання розрахунку густини

та теплоти природного газу

\begin{tabular}{|c|c|c|c|c|c|c|}
\hline Компонент & $\begin{array}{c}\text { Нормована } \\
\text { молярна } \\
\text { частка в газі } \\
\end{array}$ & Густина & $\begin{array}{c}\text { Вміст } \\
\text { № } 1\end{array}$ & $\begin{array}{c}\text { Вміст } \\
\text { № } 2\end{array}$ & $\begin{array}{c}\text { Вміст } \\
\text { № } 3\end{array}$ & $\begin{array}{c}\text { Вмiст } \\
\text { № } 4\end{array}$ \\
\hline Метан & $\geq 0,9$ & 0,665 & 0,9 & 0,9768 & 0,95 & 0,94 \\
\hline Діоксид вуглецю & $\leq 0,02$ & 1,833 & 0,02 & 0 & 0,02 & 0,02 \\
\hline Азот & $\leq 0,05$ & 1,160 & 0,05 & 0 & 0 & 0,01 \\
\hline Пропан & $\leq 0,03$ & 1,858 & 0,026 & 0,0232 & 0,026 & 0,026 \\
\hline Бутан & $\leq 0,02$ & 2,485 & 0,004 & 0 & 0,004 & 0,004 \\
\hline \multicolumn{3}{|c|}{ Розрахована густина газу, кг/м } & 0,752 & 0,693 & $\mathbf{0 , 7 2 7}$ & $\mathbf{0 , 7 3 2}$ \\
\hline \multicolumn{3}{|c|}{ Нижча теплота згоряння, МДж/: ${ }^{3}$} & 32,66 & 34,54 & 34,34 & 34,01 \\
\hline \multicolumn{3}{|c|}{ Вища теплота згоряння, МДж/м ${ }^{3}$} & 36,20 & 38,30 & 38,07 & 37,69 \\
\hline
\end{tabular}


За результатами проведеного моделювання встановлено, вміст негорючих компонентів суттєво зменшує теплоту згоряння природного газу (Вміст № 1), оскільки частина теплової енергії, яка вивільняється при згорянні газу, затрачається на неефективний нагрів їхніх молекул. При відсутності в складі газу інертних газів та негорючих компонентів (Вміст № 2), теплота згоряння досягає максимально рекомендованого значення. За умови відомого, виміряного потоковим газоаналізатором значення діоксиду вуглецю, наприклад 2\%, і відсутності інертного газу азоту (Вміст № 3),

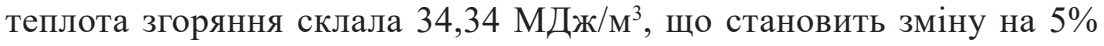
відносно значення теплоти згоряння 32,66 МДж/м ${ }^{3}$ при максимальній молярній частці азоту 5\%. Причому вплив процентного об'ємного вмісту діоксиду вуглецю на значення теплоти згоряння не настільки виражений, як азоту. Подальші експериментальні дослідження показали наявність лінійної залежності між молярною часткою азоту у відсотках та прямопропорційному зменшенні значення теплоти згоряння природного газу також у відсотках. Результати представлені на рис. 5.

Таким чином, авторами встановлено, що зміна молярної частки інертного газу азоту, максимальне значення якої встановлене в [1], прямопропорційно впливає на зміну теплоти згоряння природного

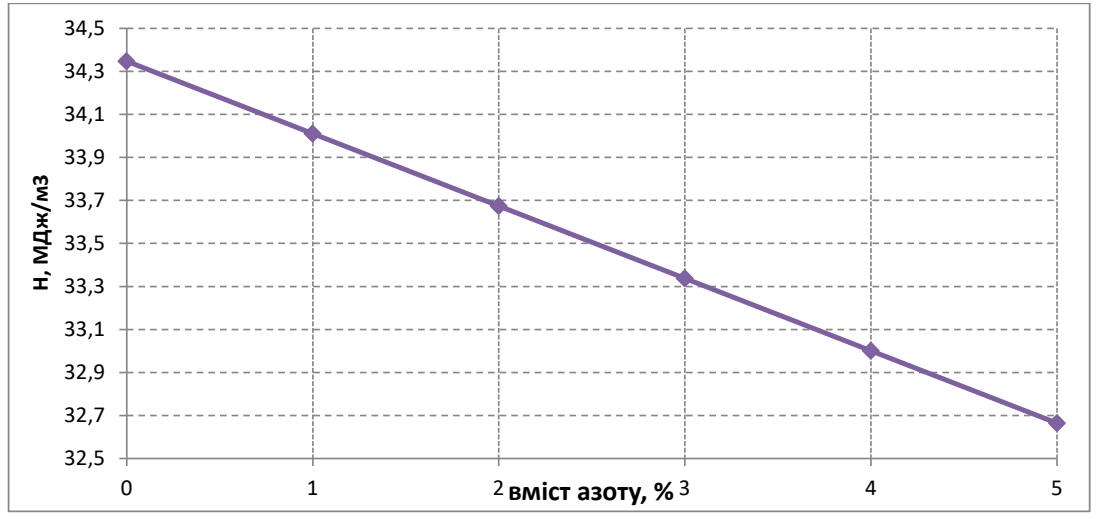

Рис. 5. Моделювання зміни нижчої теплоти згоряння природного газу при зміні молярної частки азоту в складі газу 
газу у відсотковому відношення. Тобто, змінюючи молярну частку азоту, можна здійснювати ефективне управління теплотою згоряння природного газу в законодавчо визначених межах без необхідності проведення громіздких математичних обчислень та застосувань складних систем автоматичного регулювання із зворотнім зв'язком для вимірювальних систем, які обладнані дублюючими вузлами обліку. Таке управління доцільно проводити, наприклад, для видобувних компаній, родовища газу яких «багаті», тобто мають велику молярну частку важких вуглеводнів, які можливо вилучити з газу, а його вміст доповнити азотом.

За результатами проведеного аналізу паспортів якості природного газу, які щоденно формуються ТОВ «Оператор ГТС України» i передаються до РГК на підставі проведення вимірювань фізикохімічних та якісних показників природного газу, встановлено, що середньостатистичне значення вмісту азоту в природному газі складає близько 1,3\% об'ємного вмісту з відносним коливанням в межах $\pm(0,5-0,7) \%$.

\section{7. Нормативне забезпечення ВОГ}

У відповідності до розділу 10 Правил обліку газу [6], встановлено, що найбільше розрахункове значення основної відносної похибки вимірювання об'єму газу, приведеному до стандартних умов (температури $20^{\circ} \mathrm{C}$, тиску 101,325 Па) на ВОГ повинне становити: із застосуванням методу змінного перепаду тиску $- \pm 3 \%$; із застосуванням лічильника газу $- \pm 2,5 \%$. Разом 3 тим, у нормативному документі ДСТУ OIML R 140 [18], який зазначений в Переліку національних стандартів, відповідність яким надає презумпцію відповідності засобів вимірювальної техніки суттєвим вимогам Технічного регламенту законодавчо регульованих засобів вимірювальної техніки, (наказ Мінекономрозвитку від 23.04.2019 № 717), як доказова база при проведенні оцінки відповідно ВОГ також встановлені вимоги до точності ВОГ. Перш за все слід відзначити, що вимірювальні системи поділяються на класи точності А, В та С. Аналогічно за функціоналом, вимірювальні системи розділені на системи визначення енергії природного газу та визначення об'єму або маси пройденого газу (таблиця 2). 
Таблиця 2

Максимально допустимі похибки для вимірювальних систем (ВОГ) згідно ДСТУ OIML R140

\begin{tabular}{|l|c|c|c|}
\hline $\begin{array}{c}\text { Максимальна } \\
\text { допустима похибка } \\
\text { визначення: }\end{array}$ & Клас точності А & Клас точності В & Клас точності С \\
\hline Енергії газу & $\pm 1,0 \%$ & $\pm 2,0 \%$ & $\pm 3,0 \%$ \\
\hline Об'єму та маси газу & $\pm 0,9 \%$ & $\pm 1,5 \%$ & $\pm 2,0 \%$ \\
\hline
\end{tabular}

Також в зазначеному гармонізованому стандарті вказані показники точності для складових компонентів (вимірювальних модулів) системи ВОГ в одиницях енергії (таблиця 3).

Таблиця 3

Максимально допустимі похибки модулів ВОГ при проведенні вимірювань в одиницях енергіï

\begin{tabular}{|l|c|c|c|}
\hline \multicolumn{1}{|c|}{ Назва вимірювального модуля } & $\begin{array}{c}\text { Клас } \\
\text { точності А }\end{array}$ & $\begin{array}{c}\text { Клас } \\
\text { точності В }\end{array}$ & $\begin{array}{c}\text { Клас } \\
\text { точності С }\end{array}$ \\
\hline $\begin{array}{l}\text { Вимірювання об’єму газу (без } \\
\text { приведення до стандартних умов) }\end{array}$ & $\pm 0,7 \%$ & $\pm 1,2 \%$ & $\pm 1,5 \%$ \\
\hline $\begin{array}{l}\text { Приведення об'єму газу до } \\
\text { стандартних умов або до маси газу }\end{array}$ & $\pm 0,5 \%$ & $\pm 1,0 \%$ & $\pm 1,5 \%$ \\
\hline Вимірювання теплоти згоряння газу & $\pm 0,5 \%$ & $\pm 1,0 \%$ & $\pm 1,0 \%$ \\
\hline $\begin{array}{l}\text { Визначення репрезентативного } \\
\text { значення теплоти згоряння газу }\end{array}$ & $\pm 0,6 \%$ & $\pm 1,25 \%$ & $\pm 2,0 \%$ \\
\hline Перерахунок в одиницях енергії & $\pm 0,05 \%$ & $\pm 0,05 \%$ & $\pm 0,05 \%$ \\
\hline
\end{tabular}

За результатами проведеного аналізу таблиць 2 та 3 встановлено, що для визначення репрезентативного значення теплоти згоряння природного газу для класів точності вимірювальних систем обліку природного газу нормована похибка складає: $\pm 1,25 \%$ (клас В) та $\pm 2,0 \%$ (клас C). Таким чином, можна стверджувати, що за умови занесення до інформаційно-вимірювальної системи обчислювача вузла обліку газу сталого значення азоту на рівні 1,3\% об'ємного вмісту газу, то 3 великою ймовірністю можна констатувати, що зміна його вмісту протягом розрахункового періоду не виходитиме за межі похибки для класу точності В, відповідно, і для класу С аналогічно. 


\section{8. Висновки}

В роботі проведено дослідження щодо визначення значення теплоти згоряння природного газу на основі розрахунково отриманої густини газу за даними вимірювальної системи, яка обладнана дублюючим вузлом обліку. Запропонована процедура розрахунку густини природного газу на основі значення масової та об'ємної витрати газу, вимірювання яких здійснюється в умовах вимірювальної системи, яка обладнана основним вузлом на базі методу змінного перепаду тиску та дублюючим вузлом із застосуванням лічильника газу. Така конфігурація дозволяє визначити розрахунково значення густини газу та за відомою залежністю встановити вищу та нижчу теплоту згоряння природного газу без встановлення потокових засобів вимірювання теплоти згоряння. Також здійснене моделювання зміни теплоти згоряння природного газу в залежності від об'ємного вмісту негорючих компонентів. Виявлено прямопропорційну залежність впливу об'ємного вмісту азоту на зміну теплоти згоряння газу та запропонований спосіб здійснення управління теплотою згоряння природного газу шляхом зміни вмісту азоту в законодавчо встановлених межах. Здійснений аналіз нормативного забезпечення вимірювальних систем обліку природного газу та встановлено, що зміна вмісту азоту в газі протягом розрахункового періоду знаходиться в межах точності, яка відповідає класу В та С, згідно ДСТУ OIML R140.

\section{Список літератури:}

1. Кодекс газотранспортної системи, затверджений Постановою Національної комісія, що здійснює державне регулювання у сферах енергетики та комунальних послуг № 2493 від 30.09.2015.

2. Кодекс газорозподільних систем, затверджений Постановою Національної комісія, що здійснює державне регулювання у сферах енергетики та комунальних послуг № 2494 від 30.09.2015.

3. Кодекс газосховищ та критеріїв, згідно з якими до певного газосховища застосовується режим договірного доступу або режим регульованого доступу, затверджений Постановою Національної комісія, що здійснює державне регулювання у сферах енергетики та комунальних послуг № 2495 від 30.09.2015.

4. Правил обліку природного газу під час його транспортування газорозподільними мережами, постачання та споживання, затверджені Наказом Міністерства палива та енергетики України № 618 від 27.12.2005.

5. Закон України «Про ринок природного газу». Відомості Верховної Ради (ВBP). 2015. № 27, ст. 234. 
6. Проект Правила визначення обсягів природного газу, вихідний лист Міністерства енергетики та вугільної промисловості України № 01/31-1649 від 27.02.2018.

7. Технічний регламент засобів вимірювальної техніки, затверджений Постановою Кабміну № 163 від 24 лютого 2016.

8. Технічний регламент законодавчо регульованих засобів вимірювальної техніки, затверджений Постановою Кабміну № 194 від 13 січня 2016.

9. ДСТУ ISO 15112:2019 Природний газ. Визначення енергії (ISO 15112:2018, IDT)

10.РД 50-213-80 Правила измерения расхода газов и жидкостей стандартными сужающими устройствами.

11. ДСТУ ГОСТ 8.586.1:2009 (ИСО 5167-1:2003) Метрологія. Вимірювання витрати та кількості рідини й газу із застосуванням стандартних звужувальних пристроїв. Частина 1. Принцип методу вимірювання та загальні вимоги (ГОСТ 8.586.1-2005 (ИСО 5167-1:2003), IDT; ISO 5167-1:2003, NEQ).

12.ДСТУ ISO 17089-1:2014 Вимірювання потоку плинного середовища в закритих каналах. Ультразвукові лічильники газу. Частина 1. Лічильники для комерційного обліку та вимірювання в газорозподільчих системах. (ISO 17089-1:2010, IDT).

13. Саєвич І.Б., Джочко П.Я., Середюк Д.О., Пелікан Ю.Т., Бас О.А. Калібру-вальна установка в діапазоні об'ємної витрати газу до $7000 \mathrm{~m}^{3} /$ год // XVIII Міжнародна науково-технічна конференція «ПРИЛАДОБУДУВАННЯ: стан і перспективи», 15-16 травня 2018 року, КП ім. Ігоря Сікорського, Київ. С. 215-216.

14.ДСТУ EN 16726:2019 Газова інфраструктура. Якість газу. Група Н (EN 16726:2015 + A1:2018, IDT).

15.ДСТУ ISO 15971:2014 Природний газ. Вимірювання властивостей. Теплота згоряння та число Воббе (ISO 15971:2008, IDT).

16.Петришин I.C. Присяжнюк T.I., Петришин Н.I., Бас О.А., Данів В.М. Аналіз i оцінка метрологічних характеристик вимірювальної системи енергетичної цінності природного газу. Метрологія та прилади. 2015. № 4(54). C. 21-27.

17.ГОСТ 30319.1-96 Газ природный. Методы расчета физических свойств. Определение физических свойств природного газа, его компонентов и продуктов его переработки.

18. ДСТУ OIML R 140:2014 Вимірювальні системи для газового палива (OIML R 140, edition 2007, IDT).

\section{References:}

1. Kodeks hazotransportnoi systemy, zatverdzhenyi Postanovoiu Natsionalnoi komisiia, shcho zdiisniuie derzhavne rehuliuvannia u sferakh enerhetyky ta komunalnykh posluh № 2493 vid 30.09.2015.

2. Kodeks hazorozpodilnykh system, zatverdzhenyi Postanovoiu Natsionalnoi komisiia, shcho zdiisniuie derzhavne rehuliuvannia u sferakh enerhetyky ta komunalnykh posluh № 2494 vid 30.09.2015. 
3. Kodeks hazoskhovyshch ta kryteriiv, zghidno z yakymy do pevnoho hazoskhovyshcha zastosovuietsia rezhym dohovirnoho dostupu abo rezhym rehulovanoho dostupu, zatverdzhenyi Postanovoiu Natsionalnoi komisiia, shcho zdiisniuie derzhavne rehuliuvannia u sferakh enerhetyky ta komunalnykh posluh № 2495 vid 30.09.2015.

4. Pravyl obliku pryrodnoho hazu pid chas yoho transportuvannia hazorozpodilnymy merezhamy, postachannia ta spozhyvannia, zatverdzheni Nakazom Ministerstva palyva ta enerhetyky Ukrainy № 618 vid 27.12.2005.

5. Zakon Ukrainy «Pro rynok pryrodnoho hazu», Vidomosti Verkhovnoi Rady (VVR), 2015, № 27, st. 234.

6. Proekt Pravyla vyznachennia obsiahiv pryrodnoho hazu, vykhidnyi lyst Ministerstva enerhetyky ta vuhilnoi promyslovosti Ukrainy № 01/31-1649 vid 27.02.2018.

7. Tekhnichnyi rehlament zasobiv vymiriuvalnoi tekhniky, zatverdzhenyi Postanovoiu Kabminu № 163 vid 24 liutoho 2016.

8. Tekhnichnyi rehlament zakonodavcho rehulovanykh zasobiv vymiriuvalnoi tekhniky, zatverdzhenyi Postanovoiu Kabminu № 194 vid 13 sichnia 2016.

9. DSTU ISO 15112:2019 Pryrodnyi haz. Vyznachennia enerhii (ISO 15112:2018, IDT).

10. RD 50-213-80 Pravila izmereniya rashoda gazov i zhidkostey standartnyimi suzhayuschimi ustroystvami.

11. DSTU HOST 8.586.1:2009(YSO 5167-1:2003) Metrolohiia. Vymiriuvannia vytraty ta kilkosti ridyny y hazu iz zastosuvanniam standartnykh zvuzhuvalnykh prystroiv. Chastyna 1. Pryntsyp metodu vymiriuvannia ta zahalni vymohy (HOST 8.586.1-2005 (YSO 5167-1:2003), IDT; ISO 5167-1:2003, NEQ).

12. DSTU ISO 17089-1:2014 Vymiriuvannia potoku plynnoho seredovyshcha v zakrytykh kanalakh. Ultrazvukovi lichylnyky hazu. Chastyna 1. Lichylnyky dlia komertsiinoho obliku ta vymiriuvannia $\mathrm{v}$ hazorozpodilchykh systemakh. (ISO 17089-1:2010, IDT).

13. Saievych I.B., Dzhochko P.Ia., Serediuk D.O., Pelikan Yu.T., Bas O.A. Kalibruvalna ustanovka v diapazoni obiemnoi vytraty hazu do $7000 \mathrm{~m} 3 /$ hod // XVIII Mizhnarodna naukovo-tekhnichna konferentsiia «PRYLADOBUDUVANNIA: stan i perspektyvy», 15-16 travnia 2018 roku, KPI im. Ihoria Sikorskoho, Kyiv. S. 215-216.

14. DSTU EN 16726:2019 Hazova infrastruktura. Yakist hazu. Hrupa H (EN 16726:2015 + A1:2018, IDT).

15. DSTU ISO 15971:2014 Pryrodnyi haz. Vymiriuvannia vlastyvostei. Teplota zghoriannia ta chyslo Vobbe (ISO 15971:2008, IDT).

16. Petryshyn I.S. Prysiazhniuk T.I., Petryshyn N.I., Bas O.A., Daniv V.M. Analiz i otsinka metrolohichnykh kharakterystyk vymiriuvalnoi systemy enerhetychnoi tsinnosti pryrodnoho hazu. Metrolohiia ta prylady. 2015. № 4(54). S. 21-27.

17. GOST 30319.1-96 Gaz prirodnyiy. Metodyi rascheta fizicheskih svoystv. Opredelenie fizicheskih svoystv prirodnogo gaza, ego komponentov i produktov ego pererabotki.

18. DSTU OIML R 140:2014 Vymiriuvalni systemy dlia hazovoho palyva (OIML R 140, edition 2007, IDT). 